\title{
Dr. William Thomas Duffy Statement
}

\author{
Nick Kostovic* \\ Bio Technological Health Center, Inc., 3838 Carson Street, Suite 307, Torrance, CA 90503, Los Angeles, USA
}

I was collaborating and monitoring Nick Kostovic's technology of bio electricity for a few years. This advanced technology which he invented seems like science fiction or some alien technology or just an impossibility, but I know without a doubt that it is real and works miracles.

After he rescued the life of a patient, she suffered from six malignant brain tumors and multiple lesions with no side effects absolutely safe, and no harm to the healthy cells, I decided to invite him to leave his office in San Pedro, CA and to share my office in Northridge CA. It doesn't matter how eminent or major, any Institute or Hospital is in the world they can't match such an advanced technology. It is unheard of to rescue a cancer patient with brain tumors and restore her life without surgery!

Nick happily accepted my invitation and began to perform bio electricity therapy in my office in Northridge, working with my patients till the time I retired. Under my supervision he performed with biological electricity on brain cancers, heart attacks and Parkinson's. He successfully accomplished extraordinary results beyond any technology yet developed today in US and the world. It is not only a powerful healing process, it is also repaired and returned the lost functioning of the metabolism, mobility and motor functions. This technology is not only powerful in healing, but also as a prevention, rehabilitation and regeneration tool.

For the first time ever in human civilization this device enables us the capacity to maintain all of our physical organs. This device cleanses the body by burning away and dispersing the dead and dying fiber tissue cells, oxidized proteins and numerable sick cells from the healthy fiber tissue in the any organ throughout the body. It can even clean the capillaries, veins and arteries of plaque enabling the healthy blood supply of oxygen and proteins to reach and nourish the organs. This device is new to our human civilization; I believe our future civilization will be indebted to Nick for his discovery.

But Nick never stopped his discoveries. He utilized his father Ivo Kostovic's top secret military research (while working for the former Yugoslavian Government). Nick also based his research on his great grand uncle Nikola Tesla. Tesla mastered electromagnetics. Nick also researched German Physicist. Werner Karl Heisenberg who was a master in discovering Quantum Mechanics and quanta light particles.

With all of his combined research Nick achieved something which looks impossible. Nick's discovery of using this energetic technology has produced a circumstance which can not only heal but amazingly

Copyright: (C2016 Kostovic N. This is an open-access article distributed under the terms of the Creative Commons Attribution License, which permits unrestricted use, distribution, and reproduction in any medium, provided the original author and source are credited. nourish brain nerve cells, to awaken hibernating brain nerve cells. At the same time nourishing and stimulating the lower sequence of brain nerve cells. It was unknown until now that we humans have a number of lower sequence brain nerve cells. Until now there was no way to attract these quanta light particles (which belong to Fermions a subgroup of Quarks). Nick's discovery can attract these particles transferred through Leptons /sun light/ and sent through the human hair follicle which then can supply the brain's lower sequence. Lower sequences when gently stimulated with this biological electricity cancreate "new life cycles". Imagine producing a new life cycle of another $80-90$ years, Nick has discovered that there are multiple life cycles.

Nick also produced circumstances that have opened the "dots" of quanta light particles making visible the elemental gluon or quark structure. One of Nick's discovery was making visible a number of elemental particles including electron neutrinos, released from/Leptons group/ sun's ray dots particles. Interaction of these values with the finest bio electricitysupply to the brain starts awakening the next life cycle of the brain nerve cell sequence. Of course this is only after treatments of cleaning piles of dead brain cells from the brain. This cleaning (which has never been done before)is the clue to this unbelievable process.

Nick has explained that in Nature the brain nerve cells in these lower sequences exist. For example the Greenland Shark lives more than 300 years, as well as Galapagos Turtle living $250-260$ years or more. They have obviously achieved three or four life cycles by awakening the lower brain nerve cells sequences, one by one. Nick has studied this essential phenomena and how it happens in nature.

He understands some of the other clues which speaks to Nature's prerequisite cleaning process of these creatures fiber tissue. But I won't go into that at this time. Under the Himalayan slopes some tribes live for 110-120 years. The former Yugoslavian Government, 40 years ago researched these tribes that live such a long life, not prone to diseases. Nick has found that their nerve brain cells lower sequence is partially opened and stimulated due to the minerals and angle of the sun's rays on their environment.

Sadly the US bureaucracy is very slow, but I have no doubt that Nick Kostovic's advanced technological discoveries will sooner or later be recognized throughout the US and the World.

Correspondence to: Nick Kostovic, Bio Technological Health Center, Inc., 3838 Carson Street, Suite 307, Torrance, CA 90503, Los Angeles, USA, Tel: +1-310-543-0309/+1-310-381-9105; Fax: +1-310-540-6946; E-mail: nick@ kbhealthcenter.com

Received: October 05, 2016; Accepted: October 20, 2016; Published: October 24,2016 